\title{
Oncology
}

\section{Final Safety and Efficacy Analysis of a Phase I/II Trial with Imatinib and Vinorelbine for Patients with Metastatic Breast Cancer}

\author{
Nicolai Maass ${ }^{d}$ Christian Schem $^{a}$ Dirk O. Bauerschlag ${ }^{d}$ \\ Katharina Tiemann $^{c}$ Fritz W. Schaefer ${ }^{a}$ b Sven Hanson $^{e}$ \\ Mathias Muth ${ }^{\mathrm{e}}$ Monika Baier $^{\mathrm{e}}$ Marion T. Weigel ${ }^{\mathrm{a}}$ Antonia S. Wenners ${ }^{\mathrm{a}}$ \\ Ibrahim Alkatout $^{a} \quad$ Maret Bauer $^{a}$ Walter Jonat ${ }^{a}$ Christoph Mundhenke ${ }^{a}$ \\ ${ }^{a} O B / G Y N$, Breast Unit and ${ }^{b} O B / G Y N$, Breast Unit and Diagnostic Radiology, \\ University Hospital of Schleswig-Holstein, University of Kiel, Kiel, ' Institute for \\ Hematopathology Hamburg, Hamburg, dOB/GYN, Breast Unit, RWTH Aachen, Aachen, \\ and ${ }^{e}$ Novartis Pharma GmbH, BU Oncology, Nuremberg, Germany
}

\section{Key Words}

Phase I/II trial · Metastatic breast cancer - Imatinib mesylate $\cdot$ Vinorelbine $\cdot$ KIT .

PDGFR- $\alpha$ and $-\beta$

\begin{abstract}
Background: Imatinib is a tyrosine kinase inhibitor of $B C R-A B L, A B L, P D G F R-\alpha$ and $-\beta, K I T$, and DDR. In solid tumors, it inhibits proliferation and invasiveness and facilitates higher intratumoral cytotoxic drug concentrations. Vinorelbine has good tolerability and efficacy in metastatic breast cancer (MBC). This study evaluates the safety and efficacy of imatinib and vinorelbine in combination. Methods: In a prospective, open-label, phase I/II trial, $400 \mathrm{mg}$ imatinib p.o. daily (corrected from $600 \mathrm{mg}$ ) was combined with an escalating dose of vinorelbine i.v. weekly in four dose levels of $10,15,20$, and $25 \mathrm{mg} / \mathrm{m}^{2}$ (each $\mathrm{n} \geq 5$ ) to treat patients with MBC (expressing PDGFR- $\alpha$ and/or $-\beta$, and/or KIT). The last patient of each level was treated for $>28$ days, before enrolment for the next dose level started. Study endpoints were feasibility and tolerability, incidence of hematological and nonhematological toxicity, and clinical efficacy (data cutoff: November 18, 2011). A total of 33 patients have been enrolled, and all dose levels have been fully recruited. One patient is still on study medication. A translational subprotocol is ongoing. Results: All 33 included patients are evaluable for safety (32 within the ITT population). Eleven patients were excluded early from the study (progressive disease, toxicity, and withdrawal of consent). Twenty-two patients participated in the study for $>28$ days ('ITT $\left.>28^{\prime}\right)$. Within the ITT population, the response rate [complete response (CR) and partial response (PR)] was 9.4\% $(n=3)$, the clinical benefit rate (CBR; $C R+P R+$ stable disease) $50 \%(n=$ 16), and the median time to progression (TTP) 155 days. A total of $21.3 \%$ of the patients were
\end{abstract}




\section{Oncology}

Maass et al.: Final Safety and Efficacy Analysis of a Phase I/II Trial with Imatinib and Vinorelbine for Patients with Metastatic Breast Cancer

on study medication for $>6$ months, and $15.2 \%$ for $>12$ months (mean 140 days, range $15-$ 643). Within 'ITT > 28', the response rate was $13.6 \%$, CBR $72.7 \%$, and median TTP 176 days. The response was independent of the receptor status (PDGFR- $\alpha,-\beta$, and KIT). Toxicities were as follows (safety population): $21.6 \%$ severe leukopenia, $9.1 \%$ severe neutropenia (with 1 febrile neutropenia), 1 case of bowel perforation, 36\% diarrhea (3\% severe), $84.8 \%$ nausea (severe $15.2 \%), 48.5 \%$ vomiting (severe 9.1\%), 27.3\% infections (severe 6.1\%), 12.1\% peripheral neuropathy (severe $9.1 \%$ ), and $36.4 \%$ dyspnea (3\% severe). Four patients on trial died (nondrugrelated). Conclusion: The combination of imatinib and vinorelbine in MBC appeared to be feasible and tolerable. A CBR of 50\% (ITT) in pretreated patients suggests that this combination may be active. Although toxicities were frequent, they appeared to be manageable.

(c) 2014 S. Karger AG, Basel

\section{Introduction}

Imatinib (Gleevec ${ }^{\circledR}$; Novartis Pharmaceuticals) is a tyrosine kinase inhibitor and was originally developed for targeted inhibition of the Philadelphia chromosome-related oncoprotein BCR-ABL in chronic myeloid leukemia [1,2]. Imatinib is also able to inhibit receptor tyrosine kinases such as KIT, PDGFR- $\alpha$ and $-\beta$, DDR-1, and -2 , which are important receptors in solid cancers [3]. These receptor tyrosine kinases have physiological functions in regulation of cell proliferation and differentiation, modulation of cellular metabolism, and promotion of cell survival. KIT aberrations are pathognomonic in gastrointestinal stroma tumors and are also found in different solid tumors as breast cancer [3-10]. PDGFR- $\alpha$ and $-\beta$ activation occurs via an autocrine pathway or by paracrine effects of ligands. Inhibition of both subtypes leads to apoptosis. Coexpression of PDGFR- $\beta$ and stimulating ligands can be seen in breast cancer and other solid malignancies. Increased stromal expression of PDGF receptors correlates with high-grade estrogen receptor negativity and HER-2/neu positivity. Especially PDGFR- $\beta$ expression correlates with shorter recurrence-free and overall survival and an increased risk of distant metastasis as well as with decreased chemotherapy sensitivity [11-14]. Our previous data show an antiproliferative and proapoptotic effect of imatinib in breast cancer cell lines mainly mediated by inhibition of PDGFR- $\beta$ and akt. Minor effects of KIT and PDGFR- $\alpha$ inhibition cannot be ruled out $[9,15]$. Mediated by inhibition of PDGFR- $\beta$, imatinib leads to a decrease in interstitial fluid pressure of solid tumors, which leads to increased tumor oxygenation, helps to promote an intracellular uptake of cytotoxic agents, and improve sensitivity of cancer cells to cytostatic drugs [16]. Imatinib as a single agent has only minor inhibitory effects on breast cancer cells and no significant effects in early phase clinical trials of metastasized breast cancer $[15,17]$. As tumor biology in solid tumors is driven by multiple factors, a combination of established cytotoxic agents and novel targeted drugs appears to be reasonable [18]. In advanced breast cancers, effective new combinations with limited toxicity are awaited. Imatinib is showing an enhanced radio- and chemosensitivity mediated by inhibition of PDGFR- $\beta[19,20]$.

In different phase II clinical trials, imatinib has been tested in combinations with paclitaxel, docetaxel, and capecitabine. The combination of paclitaxel and imatinib showed an overall response rate (RR) of $13.2 \%$ and an overall clinical benefit rate (CBR) of $47.4 \%$ [20]. Docetaxel and imatinib yielded an RR of $16 \%$ and a CBR of $26 \%$ [21]. Imatinib and capecitabine resulted in an RR of $11 \%$ and a CBR of $53 \%$ [22]. The combinations were moderately tolerated with common grade 3 toxicities as neutropenia, fatigue, diarrhea, and palmar-plantar erythrodysesthesia.

Vinorelbine has good tolerability and efficacy in metastatic breast cancer (MBC) as a single agent. After previous taxane and anthracycline therapies in the metastatic setting, it has produced varying results with RRs from 25 to $46 \%$ and a time to progression (TTP) of up 


\section{Oncology}

Maass et al.: Final Safety and Efficacy Analysis of a Phase I/II Trial with Imatinib and

Vinorelbine for Patients with Metastatic Breast Cancer

to 3 months. In numerous clinical trials, it has also served as a well-tolerated combination partner for other agents. Therefore, it was chosen as a combination partner for imatinib. Since a lower vinorelbine concentration led to the same inhibition of cell growth in combination with imatinib, we assume that a combination with imatinib may reduce unwanted side effects of chemotherapy [11, 12, 23-28].

In this open-label, single arm, phase I dose-escalating study (study ID CSTI571 \#BDE28, ClinicalTrials.gov Identifier:NCT 00372476), the feasibility and efficacy of this drug combination is investigated for the first time clinically. The study combines imatinib mesylate with vinorelbine weekly for patients with locally advanced or metastasized breast cancer.

\section{Material and Methods}

\section{Patient Eligibility}

Eligible patients were aged $\geq 18$ years and had measurable HER-2-/neu-negative MBC. Patients must have progressed on $\geq 1$ previous regimen for metastatic disease and must have had a previous anthracyclinecontaining chemotherapy. In addition, the tumor must have an immunohistochemical (IHC) documentation of c-kit and/or PDGFR expression and must be evaluable (as defined by Southwestern Oncology Group Solid Tumor Response Criteria). Prior therapy with vinorelbine or imatinib was not allowed. All patients had to have a performance status of 0,1 or 2 (ECOG) and adequate hematologic, cardiac, renal, and hepatic function as indicated by an absolute neutrophil count $>1,500$ cells $/ \mu$ l, platelets $>100,000 \mathrm{k} / \mathrm{mm}^{3}$, creatinine clearance $>60 \mathrm{ml} / \mathrm{min}$, bilirubin within normal institutional limits, and aspartate aminotransferase as well asalanine aminotransferase $<2.5$ times the normal institutional limit. Patients were excluded if they had brain or CNS metastases, were pregnant, were HIV positive, had another invasive cancer within 5 years or any previous cancer not in remission or severe and/or uncontrolled medical disease (i.e., uncontrolled diabetes, chronic renal disease, or active uncontrolled infection).

The study has been performed in accordance with the local review board (ethics committee). All patients were informed of the investigational nature of the study and gave written informed consent.

\section{Study Endpoints}

In this phase I/II clinical trial, the primary objectives under evaluation were safety and tolerability (total toxicity, incidence of hematological toxicity/grade 3 and 4 and of nonhematological toxicity/grade 3 and 4) of this novel drug combination. Toxicities were classified using the Common Toxicity Criteria (CTC) grade (CTCAE Version 3.0). Secondary endpoints were clinical activity of the combination, such as clinical RR and TTP [27], using the SWOG response criteria. Patients with missing tumor response or who died or discontinued the study before having the first post-baseline assessment were considered to be nonresponders. In addition, quality of life (according to the EORTC QLQ-C30 and BR23 questionnaires) was measured at specific time points during the course of treatment. Before study admission, tumors had to proof expression of either c-kit and/or PDGFR by IHC stain of paraffin-embedded tumor tissue from a primary diagnosis or metastasis.

\section{Study Treatment}

A treatment cycle consisted of $400 \mathrm{mg}$ imatinib p.o. daily on days 1-28. The imatinib dose was lowered from $600 \mathrm{mg}$ to $400 \mathrm{mg}$ daily because of toxicity (primarily nausea and other gastrointestinal disturbances) observed in the first 6 patients. Additionally a vinorelbine dose escalation was performed in four levels. Patients received i.v. cycles of vinorelbine at $10 \mathrm{mg} / \mathrm{m}^{2}$ (level 1), $15 \mathrm{mg} / \mathrm{m}^{2}$ (level 2), $20 \mathrm{mg} / \mathrm{m}^{2}$ (level 3) or $25 \mathrm{mg} / \mathrm{m}^{2}$ (level 4) weekly on days 1-28. During the first cycle, vinorelbine was given on days 8-28. In 5 patients, the levels were reached one after the other. Patients were assigned to one dose level and were exclusively treated within this dose level. Recruitment started for the lowest vinorelbine dose level. When the dose levels were all filled and no limiting toxicities occurred (in $\leq 1$ of 5 patients) for at least 28 days, recruitment for the next higher dose level started. When patients withdrew their consent or were not evaluable for at least 28 days on treatment, they were excluded from the study and an additional patient was recruited for this dose level. In case of severe side effects or progressive disease (PD), patients were also excluded from the study. In case of remission or stable disease (SD), patients continued treatment.

The first patient visit occurred in June 2006, and 33 patients from one center were enrolled and treated in this study. The last patient completed the trial in July 2012. 


\section{Oncology}

\begin{tabular}{l|l}
\hline Oncology 2014;87:300-310 \\
\hline DOI: 10.1159/000365553 & $\begin{array}{l}\text { @ 2014 S. Karger AG, Basel } \\
\text { www.karger.com/ocl }\end{array}$ \\
\hline
\end{tabular}

Maass et al.: Final Safety and Efficacy Analysis of a Phase I/II Trial with Imatinib and Vinorelbine for Patients with Metastatic Breast Cancer

Table 1. Overall exposure in the safety population

\begin{tabular}{|c|c|c|c|c|c|c|}
\hline \multirow{2}{*}{$\begin{array}{l}\text { Imatinib/ } \\
\text { vinorelbine }\end{array}$} & \multicolumn{5}{|c|}{ Overall exposure } & \multirow{2}{*}{$\begin{array}{l}\text { Total } \\
(n=33)\end{array}$} \\
\hline & $\begin{array}{l}600 \mathrm{mg} / \\
10 \mathrm{mg} / \mathrm{m}^{2} \\
(\mathrm{n}=6)\end{array}$ & $\begin{array}{l}400 \mathrm{mg} / \\
10 \mathrm{mg} / \mathrm{m}^{2} \\
(\mathrm{n}=5)\end{array}$ & $\begin{array}{l}400 \mathrm{mg} / \\
15 \mathrm{mg} / \mathrm{m}^{2} \\
(\mathrm{n}=10)\end{array}$ & $\begin{array}{l}400 \mathrm{mg} / \\
20 \mathrm{mg} / \mathrm{m}^{2} \\
(\mathrm{n}=6)\end{array}$ & $\begin{array}{l}400 \mathrm{mg} / \\
25 \mathrm{mg} / \mathrm{m}^{2} \\
(\mathrm{n}=6)\end{array}$ & \\
\hline \multicolumn{7}{|c|}{ Duration category in days, $\mathrm{n}(\%)^{\mathrm{a}}$} \\
\hline $1-28$ & $3(50.0)$ & 0 & $3(30.0)$ & $2(33.3)$ & 0 & $8(24.2)$ \\
\hline $29-84$ & $1(16.7)$ & $3(60.0)$ & $2(20.0)$ & $2(33.3)$ & $2(33.3)$ & $10(30.3)$ \\
\hline $85-182$ & $1(16.7)$ & 0 & $3(30.0)$ & $2(33.3)$ & $2(33.3)$ & $8(24.2)$ \\
\hline $183-365$ & 0 & 0 & $2(20.0)$ & 0 & 0 & $2(6.1)$ \\
\hline$>365$ & $1(16.7)$ & $2(40.0)$ & 0 & 0 & $2(33.3)$ & $5(15.2)$ \\
\hline \multicolumn{7}{|c|}{ Duration in days ${ }^{\mathrm{a}}$} \\
\hline Mean \pm SD & $109 \pm 178$ & $209 \pm 216$ & $95 \pm 79$ & $66 \pm 47$ & $261 \pm 289$ & $140 \pm 177$ \\
\hline Median & 32 & 63 & 83 & 60 & 115 & 63 \\
\hline Range & $15-468$ & $44-484$ & $15-204$ & $22-147$ & $29-643$ & $15-643$ \\
\hline \multicolumn{7}{|c|}{ Average daily dose of vinorelbine ${ }^{b}$} \\
\hline Mean \pm SD & $2.4 \pm 0.5$ & $2.4 \pm 0.3$ & $3.7 \pm 0.4$ & $4.1 \pm 0.6$ & $4.3 \pm 0.6$ & $3.4 \pm 0.9$ \\
\hline Median & 2.5 & 2.4 & 3.8 & 3.9 & 4.3 & 3.7 \\
\hline Range & $1.9-3.1$ & $2.0-2.9$ & $2.8-4.1$ & $3.5-5.0$ & $3.3-5.0$ & $1.9-5.0$ \\
\hline
\end{tabular}

Eight patients discontinued trial medication early ( $<28$ days). One patient was still on trial at the date of the data cutoff. At least one change of the imatinib dose was reported in $42.4 \%$ of the patients (most frequent reason: dose after recovery) and at least one change of the vinorelbine dose was reported in $78.8 \%$ of the patients (most frequent reason: hematological toxicity NCI CTC grades 3-4). One patient at the $400 \mathrm{mg} / 15$ $\mathrm{mg} / \mathrm{m}^{2}$ dose level received only imatinib.

${ }^{\mathrm{a}}$ Imatinib + vinorelbine; ${ }^{\mathrm{b}}$ vinorelbine was administered weekly.

\section{IHC Detection of KIT and PDGFR- $\alpha$ and $-\beta$}

Tumor sections were deparaffinized in xylene and rehydrated with graded alcohols. Epitope retrieval was performed before application of primary antibodies. Slides were incubated at room temperature. For staining of KIT, PDGFR- $\alpha$ and - $\beta$ primary antibody incubation was $40 \mathrm{~min}$ followed by Envision+ labeled polymer for $30 \mathrm{~min}$ and $\mathrm{DAB}+$ substrate for $5 \mathrm{~min}$ (Dako). Sections were counterstained with hematoxylin. Results of all antibodies were scored in a semiquantitative fashion $(0,1+, 2+, 3+)$ on the basis of the percentage of positive cells.

\section{Statistical Methods}

Analysis populations were defined as follows: The safety population included all patients who received at least one dose of imatinib or vinorelbine. The ITT (intent-to-treat) population included all enrolled patients who received at least one dose of imatinib and vinorelbine. The population analyzable for efficacy consisted of all patients who received the study drug combination for at least 3 weeks. Efficacy evaluation: best overall response. The crude RR was calculated based on the investigator's assessment. A Kaplan-Meier estimator together with the corresponding 95\% confidence interval (CI) was additionally presented. TTP was presented as Kaplan-Meier curve and median TTP was planned to be compared against historical controls.

\section{Results}

All 33 patients included in this trial were evaluable for safety. A total of 32 patients were part of the ITT population. Five different dose levels have been assigned to the patients. Ten patients were older than 65 years, with a mean age of 60.2 years (42-71). All, but 1 patient were postmenopausal. Eleven patients were excluded early from the study (PD, toxicity, and withdrawal of consent). Twenty-two (67\%) patients participated in the study for $>28$ days 
Table 2. Presentation of the most frequent $\mathrm{AEs}^{\mathrm{a}}$ in the safety population

\begin{tabular}{|c|c|c|c|c|c|c|}
\hline \multirow[t]{2}{*}{ Imatinib/vinorelbine } & \multicolumn{5}{|c|}{ Most frequent AEs } & \multirow[t]{2}{*}{ Total } \\
\hline & $\begin{array}{l}600 \mathrm{mg} / \\
10 \mathrm{mg} / \mathrm{m}^{2}\end{array}$ & $\begin{array}{l}400 \mathrm{mg} / \\
10 \mathrm{mg} / \mathrm{m}^{2}\end{array}$ & $\begin{array}{l}400 \mathrm{mg} / \\
15 \mathrm{mg} / \mathrm{m}^{2}\end{array}$ & $\begin{array}{l}400 \mathrm{mg} / \\
20 \mathrm{mg} / \mathrm{m}^{2}\end{array}$ & $\begin{array}{l}400 \mathrm{mg} / \\
25 \mathrm{mg} / \mathrm{m}^{2}\end{array}$ & \\
\hline $\begin{array}{l}\text { Total number of patients } \\
\text { Total number of patients }\end{array}$ & $6(100.0)$ & $5(100.0)$ & $10(100.0)$ & $6(100.0)$ & $6(100.0)$ & $33(100.0)$ \\
\hline with AEs & $6(100.0)$ & $5(100.0)$ & $10(100.0)$ & $6(100.0)$ & $6(100.0)$ & $33(100.0)$ \\
\hline Total number of AEs & 52 & 58 & 112 & 62 & 243 & 527 \\
\hline \multicolumn{7}{|l|}{ AE preferred term } \\
\hline Nausea & $6(100.0)$ & $4(80.0)$ & $9(90.0)$ & $5(83.3)$ & $5(83.3)$ & $29(87.9)$ \\
\hline Fatigue & $2(33.3)$ & $4(80.0)$ & $7(70.0)$ & $2(33.3)$ & $5(83.3)$ & $20(60.6)$ \\
\hline Vomiting & $3(50.0)$ & $2(40.0)$ & $5(50.0)$ & $3(50.0)$ & $3(50.0)$ & $16(48.5)$ \\
\hline Diarrhea & $3(50.0)$ & $2(40.0)$ & $3(30.0)$ & $2(33.3)$ & $2(33.3)$ & $12(36.4)$ \\
\hline Dyspnea & $1(16.7)$ & $2(40.0)$ & $5(50.0)$ & $1(16.7)$ & $3(50.0)$ & $12(36.4)$ \\
\hline Hemoglobin decreased & 0 & $1(20.0)$ & $3(30.0)$ & $2(33.3)$ & $3(50.0)$ & $9(27.3)$ \\
\hline Leukopenia & 0 & 0 & $2(20.0)$ & $3(50.0)$ & $4(66.7)$ & $9(27.3)$ \\
\hline Pain in extremity & 0 & $2(40.0)$ & $4(40.0)$ & $1(16.7)$ & $2(33.3)$ & $9(27.3)$ \\
\hline Abdominal pain & 0 & $1(20.0)$ & $1(10.0)$ & $2(33.3)$ & $3(50.0)$ & $7(21.2)$ \\
\hline Decreased appetite & 1 (16.7) & $0(0.0)$ & $2(20.0)$ & $1(16.7)$ & $2(33.3)$ & $6(18.2)$ \\
\hline Pleural effusion & $2(33.3)$ & $2(40.0)$ & $1(10.0)$ & $1(16.7)$ & 0 & $6(18.2)$ \\
\hline Pyrexia & $1(16.7)$ & $2(40.0)$ & $1(10.0)$ & $1(16.7)$ & $1(16.7)$ & $6(18.2)$ \\
\hline AST increased & 0 & 0 & $2(20.0)$ & $1(16.7)$ & $2(33.3)$ & $5(15.2)$ \\
\hline Blood LDH increased & $1(16.7)$ & 0 & $2(20.0)$ & $1(16.7)$ & $1(16.7)$ & $5(15.2)$ \\
\hline Bone pain & 0 & 0 & $2(20.0)$ & $2(33.3)$ & $1(16.7)$ & $5(15.2)$ \\
\hline Cough & 0 & 0 & $2(20.0)$ & $1(16.7)$ & $2(33.3)$ & $5(15.2)$ \\
\hline
\end{tabular}

Values are $\mathrm{n}(\%)$. All patients in the safety population experienced at least one AE. The total number of AEs was highest at the $400 \mathrm{mg} / 25 \mathrm{mg} / \mathrm{m}^{2}$ dose level. Sort order is by decreasing incidence in the total group. $\mathrm{AST}=$ Aspartate aminotransferase; $\mathrm{LDH}=$ lactate dehydrogenase.

a $>15 \%$ in the total group.

('ITT >28') and were analyzable for efficacy. Of the 6 patients who were treated at level 1 with $600 \mathrm{mg} / 10 \mathrm{mg} / \mathrm{m}^{2}$ as originally planned, 5 discontinued the treatment due to adverse events (AEs; 1 patient on day 15 and 1 on day 17), and 1 patient withdrew her consent. In order to improve the tolerability of the study treatment, it was decided to reduce the imatinib dose to $400 \mathrm{mg}$ (amendment 2; issued on May 10, 2007). With this reduction, dose escalation starting with vinorelbine $10 \mathrm{mg} / \mathrm{m}^{2}$ weekly could be performed at the $100 \%$ level of $400 \mathrm{mg} / 25$ $\mathrm{mg} / \mathrm{m}^{2}$. One of the 6 patients treated at this dose level was still receiving study treatment at the time of the data cutoff in July 2012. The mean BMI was 25.5 (17.0-33.1), and the mean body surface area was $1.8 \mathrm{~m}^{2}$ (table 1 ).

\section{Tumor History and Current Status of Disease}

Between the first diagnosis of breast cancer and inclusion in this study, a median of $>5$ years (mean 63.7 months, range 3-235) had passed. The most frequent tumor types were invasive ductal carcinoma (72.7\%) and invasive lobular carcinoma (9.1\%). At primary diagnosis, $69.7 \%$ of the tumors were estrogen receptor-positive and $57.6 \%$ progesterone receptorpositive. All tumors were HER-2-/neu-negative. All patients received systemic antineoplastic pretreatment. Substances used included cyclophosphamide (81.8\%), paclitaxel (63.6\%), epirubicine (60.6\%), and tamoxifen (54.5\%). At study baseline, all 33 patients had locally advanced (21.2\%) or/and MBC (100\%). Before study entry, they had predominantly received 


\section{Oncology}

\begin{tabular}{l|l}
\hline Oncology 2014;87:300-310 \\
\hline DOI: 10.1159/000365553 & $\begin{array}{l}\text { @ 2014 S. Karger AG, Basel } \\
\text { www.karger.com/ocl }\end{array}$ \\
\hline
\end{tabular}

Maass et al.: Final Safety and Efficacy Analysis of a Phase I/II Trial with Imatinib and

Vinorelbine for Patients with Metastatic Breast Cancer

Table 3. Deaths and other serious or clinically significant AEs in the safety population

\begin{tabular}{lllllll}
\hline \multirow{2}{*}{$\begin{array}{l}\text { AEs, dose modifications, interruptions, } \\
\text { and discontinuation }\end{array}$} & \multicolumn{2}{l}{ Imatinib/vinorelbine } & & Total \\
\cline { 2 - 5 } & $600 \mathrm{mg} /$ & $400 \mathrm{mg} /$ & $400 \mathrm{mg} /$ & $400 \mathrm{mg} /$ & $400 \mathrm{mg} /$ \\
& $10 \mathrm{mg} / \mathrm{m}^{2}$ & $10 \mathrm{mg} / \mathrm{m}^{2}$ & $15 \mathrm{mg} / \mathrm{m}^{2}$ & $20 \mathrm{mg} / \mathrm{m}^{2}$ & $25 \mathrm{mg} / \mathrm{m}^{2}$ \\
\hline Total number of patients & $6(100.0)$ & $5(100.0)$ & $10(100.0)$ & $6(100.0)$ & $6(100.0)$ & $33(100.0)$ \\
Number of patients with AEs & $6(100.0)$ & $5(100.0)$ & $10(100.0)$ & $6(100.0)$ & $6(100.0)$ & $33(100.0)$ \\
AEs requiring dose adjustment or study drug & & & & & & \\
$\quad$ interruption & $1(16.7)$ & $1(20.0)$ & $4(40.0)$ & $5(83.3)$ & $6(100.0)$ & $17(51.5)$ \\
AEs causing study drug discontinuation & $5(83.3)$ & $1(20.0)$ & $2(20.0)$ & $0(0.0)$ & $2(33.3)$ & $10(30.3)$ \\
AEs requiring significant additional therapy & $6(100.0)$ & $4(80.0)$ & $9(90.0)$ & $6(100.0)$ & $6(100.0)$ & $31(93.9)$ \\
AEs related to imatinib & $6(100.0)$ & $3(60.0)$ & $10(100.0)$ & $4(66.7)$ & $5(83.3)$ & $28(84.8)$ \\
AEs related to vinorelbine & 0 & $3(60.0)$ & $3(30.0)$ & $2(33.3)$ & $4(66.7)$ & $12(36.4)$ \\
AEs related to comb. imatinib/vinorelbine & $2(33.3)$ & $3(60.0)$ & $7(70.0)$ & $2(33.3)$ & $4(66.7)$ & $18(54.5)$ \\
SAEs & $4(66.7)$ & $3(60.0)$ & $5(50.0)$ & $2(33.3)$ & $2(33.3)$ & $16(48.5)$ \\
SAEs causing study drug discontinuation & $2(33.3)$ & $1(20.0)$ & $1(10.0)$ & 0 & $1(16.7)$ & $5(15.2)$ \\
SAEs related to any study drug & $3(50.0)^{\mathrm{a}}$ & 0 & 0 & 0 & 0 & 0
\end{tabular}

Values are $\mathrm{n}(\%)$. The incidence of AEs requiring dose adjustment (one event at $400 \mathrm{mg} / 10 \mathrm{mg} / \mathrm{m}^{2}$ vs. 59 events at 400 $\mathrm{mg} / 25 \mathrm{mg} / \mathrm{m}^{2}$ ) augmented with increasing vinorelbine dose. Of the 59 events in the $400 \mathrm{mg} / 25 \mathrm{mg} / \mathrm{m}^{2}$ dose group, 43 events were blood and lymphatic system disorders and 12 events were gastrointestinal disorders.

AEs causing study drug discontinuation were most frequent at the $600 \mathrm{mg} / 10 \mathrm{mg} / \mathrm{m}^{2}$ dose level, whilst their incidence showed no clear dose-dependent increase in the $400 \mathrm{mg}$ imatinib + vinorelbine regimens. AEs causing study drug discontinuation, which were suspected to be related to imatinib, were one event of vomiting at the $600 \mathrm{mg} / 10 \mathrm{mg} / \mathrm{m}^{2}$ dose level, one event of nausea, and one event of vomiting at the $400 \mathrm{mg} / 25 \mathrm{mg} / \mathrm{m}^{2}$ dose level. One AE causing study drug discontinuation - polyneuropathy at the $400 \mathrm{mg} / 15 \mathrm{mg} / \mathrm{m}^{2}$ dose level - was suspected to be related to vinorelbine. One AE causing study drug discontinuation - palmarplantar erythrodysesthesia syndrome at the $600 \mathrm{mg} / 10 \mathrm{mg} / \mathrm{m}^{2}$ dose level - was suspected to be related to the combination of imatinib and vinorelbine.

AEs with suspected relationship to imatinib were predominantly gastrointestinal disorders, which occurred in all patients at the $600 \mathrm{mg} / 10 \mathrm{mg} / \mathrm{m}^{2}$ dose level and in similar proportions of patients at the other dose levels. AEs with suspected relationship to vinorelbine were most commonly nervous system disorders and blood and lymphatic system disorders, the latter occurring almost exclusively at the $400 \mathrm{mg} / 25 \mathrm{mg} / \mathrm{m}^{2}$ dose level. AEs with suspected relationship to the imatinib/vinorelbine combination were most commonly general disorders and administration site conditions such as fatigue with no clear trend when comparing the different dose levels.

SAEs occurred most frequently at the $600 \mathrm{mg} / 10 \mathrm{mg} / \mathrm{m}^{2}$ dose level; in the $400 \mathrm{mg}$ imatinib + vinorelbine regimens the SAE incidence showed no dose-dependent increase. A total of 9 SAEs in 3 patients (all at the $600 \mathrm{mg} / 10 \mathrm{mg} / \mathrm{m}^{2}$ dose level) were suspected to be related to imatinib (nausea in patient No. 1, nausea and anemia in patient No. 3, and vomiting, diarrhea, nausea, and fatigue in patient No. 4). Except for nausea in patient No. 3, which was mild, all other events were of severe intensity. None of the reported SAEs were suspected to be related to vinorelbine or the imatinib/vinorelbine combination.

${ }^{a}$ All cases were suspected to be related to imatinib.

several lines of therapies for MBC (median: 2.5, range 0-5). C-kit expression in primary tumors was positive in $35.7 \%$, PDGF-R- $\alpha$ was positive in $89.3 \%$, and PDGFR- $\beta$ was positive in $10.7 \%$.

\section{Toxicities}

All treated patients were included in the safety population. At study entry, $60 \%$ had a normal ECOG performance status (0), and $40 \%$ of the patients had ECOG performance status 1. In the ITT population, a variety of toxicities occurred: $21.6 \%$ of the patients suffered from severe leukopenia, 9.1\% from severe neutropenia (with 1 case of febrile neutropenia), and 1 case of bowel perforation was observed. A total of $36 \%$ of the patients suffered from diarrhea ( $3 \%$ severe), $84.8 \%$ from nausea (severe $15.2 \%$ ), and $48.5 \%$ from vomiting (severe $9.1 \%$ ). Infections were observed in $27.3 \%$ of the cases (severe $6.1 \%$ ), a peripheral neuropathy in $12.1 \%$ (severe $9.1 \%$ ), and dyspnea in $36.4 \%$ of the cases (3\% severe; table 2 ). 
Table 4. Incidences of AEs by maximum severity in the safety population

\begin{tabular}{|c|c|c|c|c|c|c|}
\hline \multirow[t]{2}{*}{ AEs by maximum severity } & \multicolumn{5}{|c|}{ Imatinib/vinorelbine } & \multirow[t]{2}{*}{ Total } \\
\hline & $\begin{array}{l}600 \mathrm{mg} / \\
10 \mathrm{mg} / \mathrm{m}^{2}\end{array}$ & $\begin{array}{l}400 \mathrm{mg} / \\
10 \mathrm{mg} / \mathrm{m}^{2}\end{array}$ & $\begin{array}{l}400 \mathrm{mg} / \\
15 \mathrm{mg} / \mathrm{m}^{2}\end{array}$ & $\begin{array}{l}400 \mathrm{mg} / \\
20 \mathrm{mg} / \mathrm{m}^{2}\end{array}$ & $\begin{array}{l}400 \mathrm{mg} / \\
25 \mathrm{mg} / \mathrm{m}^{2}\end{array}$ & \\
\hline Total number of patients & $6(100.0)$ & $5(100.0)$ & $10(100.0)$ & $6(100.0)$ & $6(100.0)$ & $33(100.0)$ \\
\hline \multicolumn{7}{|l|}{ Total number of patients } \\
\hline with AEs & $6(100.0)$ & $5(100.0)$ & $10(100.0)$ & $6(100.0)$ & $6(100.0)$ & $33(100.0)$ \\
\hline AEs of moderate intensity & $0(0.0)$ & $1(20.0)$ & $4(40.0)$ & $1(16.7)$ & $0(0.0)$ & $6(18.2)$ \\
\hline AEs of severe intensity & $4(66.7)$ & $2(40.0)$ & $4(40.0)$ & $4(66.7)$ & $6(100.0)$ & $20(60.6)$ \\
\hline Life-threatening AEs & $2(33.3)$ & $0(0.0)$ & $0(0.0)$ & $1(16.7)$ & $0(0.0)$ & $3(9.1)$ \\
\hline Death related to AEs & $0(0.0)$ & $2(40.0)$ & $2(20.0)$ & $0(0.0)$ & $0(0.0)$ & $4(12.1)$ \\
\hline
\end{tabular}

Values are $\mathrm{n}(\%)$. Patients at the higher vinorelbine dose levels were more likely to suffer severe AEs. At the $400 \mathrm{mg} / 25 \mathrm{mg} / \mathrm{m}^{2}$ dose level, these were predominantly blood and lymphatic system disorders. None of the life-threatening AEs were suspected to be related to study treatment.

Table 5. Efficacy results of the analyzable population

\begin{tabular}{|c|c|c|c|c|c|c|}
\hline \multirow[t]{2}{*}{ Efficacy results } & \multicolumn{5}{|c|}{ Imatinib/vinorelbine } & \multirow{2}{*}{$\begin{array}{l}\text { Total } \\
(n=22)\end{array}$} \\
\hline & $\begin{array}{l}600 \mathrm{mg} / \\
10 \mathrm{mg} / \mathrm{m}^{2} \\
(\mathrm{n}=3)\end{array}$ & $\begin{array}{l}400 \mathrm{mg} / \\
10 \mathrm{mg} / \mathrm{m}^{2} \\
(\mathrm{n}=5)\end{array}$ & $\begin{array}{l}400 \mathrm{mg} / \\
15 \mathrm{mg} / \mathrm{m}^{2} \\
(\mathrm{n}=5)\end{array}$ & $\begin{array}{l}400 \mathrm{mg} / \\
20 \mathrm{mg} / \mathrm{m}^{2} \\
(\mathrm{n}=4)\end{array}$ & $\begin{array}{l}400 \mathrm{mg} / \\
25 \mathrm{mg} / \mathrm{m}^{2} \\
(\mathrm{n}=5)\end{array}$ & \\
\hline Response $^{\mathrm{a}}$ (CR or PR) & $1(33.3)$ & $1(20)$ & $1(20.0)$ & 0 & 0 & $3(13.6)$ \\
\hline Clinical benefit (CR, PR or SD) & $2(66.7)$ & $2(40.0)$ & $5(100)$ & $2(50)$ & $5(100)$ & $16(72.7)$ \\
\hline
\end{tabular}

Values are $\mathrm{n}(\%)$. The evaluation of efficacy was a secondary objective in this study. Results of best overall response according to the investigators assessment are summarized in this table. Median TTP was 176 days (95\% CI 50-611) in the efficacy analyzable population. Due to the low sample sizes, comparison of the different dose levels was not conclusive. The evaluation of efficacy was a secondary objective in this study.

${ }^{a}$ Best overall response according to the investigators assessment.

All patients in the safety population experienced at least one AE. The incidence of AEs (grades 3 and 4 toxicities) requiring dose adjustment or study drug interruption and also the absolute number of such events augmented with increasing vinorelbine dose (one event at $400 \mathrm{mg} / 10 \mathrm{mg} / \mathrm{m}^{2}$ vs. 59 events at $400 \mathrm{mg} / 25 \mathrm{mg} / \mathrm{m}^{2}$ ). Of the 59 events in the $400 \mathrm{mg} / 25$ $\mathrm{mg} / \mathrm{m}^{2}$ dose group, 43 events were blood and lymphatic system disorders, and 12 events were gastrointestinal disorders. AEs causing study drug discontinuation were most frequent at the $600 \mathrm{mg} / 10 \mathrm{mg} / \mathrm{m}^{2}$ dose level, whilst their incidence showed no clear dose-dependent increase in the $400 \mathrm{mg}$ imatinib + vinorelbine regimens (table 3). Four patients on trial died (unrelated to study treatment; table 4).

\section{Efficacy}

Within the ITT population, the RR [complete response (CR) and partial response (PR)] was $9.4 \%(n=3)$, the CBR $(C R+P R+S D)$ was $50 \%(n=16)$, and the median TTP was 155 days. A total of $21.3 \%$ of the patients were on study medication for $>6$ months, $15.2 \%$ for $>12$ months (mean 140 days, range 15-643). Within the analyzable population ('ITT $>28$ days on 


\section{Oncology}

\begin{tabular}{l|l}
\hline Oncology 2014;87:300-310 \\
\hline DOI: 10.1159/000365553 & $\begin{array}{l}\text { @ 2014 S. Karger AG, Basel } \\
\text { www.karger.com/ocl }\end{array}$ \\
\hline $\begin{array}{l}\text { Maass et al.: Final Safety and Efficacy Analysis of a Phase I/II Trial with Imatinib and } \\
\text { Vinorelbine for Patients with Metastatic Breast Cancer }\end{array}$
\end{tabular}

Table 6. Clinical response in biological subgroups

\begin{tabular}{|c|c|c|c|c|c|c|}
\hline \multirow{2}{*}{$\begin{array}{l}\text { Receptor } \\
\text { expression in } \\
\text { the tumor }\end{array}$} & \multicolumn{5}{|c|}{ Imatinib/vinorelbine } & \multirow{2}{*}{$\begin{array}{l}\text { Total number at } \\
\text { all dose levels } \\
(\mathrm{n}=22)\end{array}$} \\
\hline & $\begin{array}{l}600 \mathrm{mg} / \\
10 \mathrm{mg} / \mathrm{m}^{2} \\
(\mathrm{n}=3)\end{array}$ & $\begin{array}{l}400 \mathrm{mg} / \\
10 \mathrm{mg} / \mathrm{m}^{2} \\
(\mathrm{n}=5)\end{array}$ & $\begin{array}{l}400 \mathrm{mg} / \\
15 \mathrm{mg} / \mathrm{m}^{2} \\
(\mathrm{n}=5)\end{array}$ & $\begin{array}{l}400 \mathrm{mg} / \\
20 \mathrm{mg} / \mathrm{m}^{2} \\
(\mathrm{n}=4)\end{array}$ & $\begin{array}{l}400 \mathrm{mg} / \\
25 \mathrm{mg} / \mathrm{m}^{2} \\
(\mathrm{n}=5)\end{array}$ & \\
\hline KIT & $\begin{array}{l}2 / 3 \text { positive: } \\
1 \times \mathrm{SD}, 1 \times \mathrm{PD} \\
1 / 3 \text { negative: } \\
1 \times \mathrm{PR}\end{array}$ & $\begin{array}{l}0 \text { positive } \\
5 / 5 \text { negative: } \\
1 \times \mathrm{PR}, 1 \times \mathrm{SD}, \\
3 \times \mathrm{PD}\end{array}$ & $\begin{array}{l}0 \text { positive } \\
5 / 5 \text { negative: } \\
1 \times \mathrm{PR}, 4 \times \mathrm{SD}\end{array}$ & $\begin{array}{l}1 / 4 \text { positive: } \\
1 \times \mathrm{SD} \\
3 / 4 \text { negative: } \\
1 \times \mathrm{SD}, 2 \times \mathrm{PD}\end{array}$ & $\begin{array}{l}4 / 5 \text { positive: } \\
3 \times \mathrm{SD}, 1 \times \mathrm{PD} \\
1 / 5 \text { negative: } \\
1 \times \mathrm{SD}\end{array}$ & $\begin{array}{l}7 / 22 \text { positive: } \\
5 \times \mathrm{SD}, 2 \times \mathrm{PD} \\
15 / 22 \text { negative: } \\
7 \times \mathrm{SD}, 5 \times \mathrm{PD} \\
3 \times \mathrm{PR}\end{array}$ \\
\hline PDGF- $\alpha$ & $\begin{array}{l}2 / 3 \text { positive: } \\
1 \times \mathrm{PR}, 1 \times \mathrm{SD} \\
1 / 3 \text { negative: } \\
1 \times \mathrm{PD}\end{array}$ & $\begin{array}{l}5 / 5 \text { positive: } \\
1 \times \mathrm{PR}, 1 \times \mathrm{SD} \\
3 \times \mathrm{PD}\end{array}$ & $\begin{array}{l}5 / 5 \text { positive: } \\
1 \times \mathrm{PR}, 4 \times \mathrm{SD}\end{array}$ & $\begin{array}{l}4 / 4 \text { positive: } \\
2 \times \mathrm{SD}, 2 \times \mathrm{PD}\end{array}$ & $\begin{array}{l}4 / 5 \text { positive: } \\
3 \times \mathrm{SD}, 1 \times \mathrm{PD} \\
1 / 5 \text { negative: } \\
1 \times \mathrm{SD}\end{array}$ & $\begin{array}{l}\text { 20/22 positive: } \\
3 \times \mathrm{PR}, 11 \times \mathrm{SD} \\
6 \times \mathrm{PD} \\
2 / 22 \text { negative: } \\
1 \times \mathrm{SD}, 1 \times \mathrm{PD}\end{array}$ \\
\hline PDGF- $\beta$ & $\begin{array}{l}0 \text { positive } \\
3 / 3 \text { negative: } \\
1 \times \mathrm{PR}, 1 \times \mathrm{SD} \\
1 \times \mathrm{PD}\end{array}$ & $\begin{array}{l}1 / 5 \text { positive: } \\
1 \times \mathrm{PD} \\
4 / 5 \text { negative: } \\
1 \times \mathrm{PR}, 1 \times \mathrm{SD} \\
2 \times \mathrm{PD}\end{array}$ & $\begin{array}{l}0 \text { positive } \\
5 / 5 \text { negative: } \\
1 \times \mathrm{PR}, 4 \times \mathrm{SD}\end{array}$ & $\begin{array}{l}0 \text { positive } \\
4 / 4 \text { negative: } \\
2 \times \mathrm{SD}, 2 \times \mathrm{PD}\end{array}$ & $\begin{array}{l}0 \text { positive } \\
5 / 5 \text { negative: } \\
4 \times \mathrm{SD}, 1 \times \mathrm{PD}\end{array}$ & $\begin{array}{l}\text { 1/22 positive: } \\
1 \times \mathrm{PD} \\
21 / 22 \text { negative: } \\
3 \times \mathrm{PR}, 12 \times \mathrm{SD} \\
6 \times \mathrm{PD}\end{array}$ \\
\hline
\end{tabular}

Correlation of receptor expression with clinical response. Overall biological subgroups are too small for statistical analysis. KIT-positive tumors appear to have a less favorable prognosis than KIT-negative tumors. PDGFR- $\alpha$ and $-\beta$ are not differentially expressed. Therefore, the influence of receptor expression on response cannot be proven.

study medication'), the RR was $13.6 \%$, the CBR $72.7 \%$ (table 5), and the median TTP 176 days. At the date of the data cutoff, 1 patient was still on study medication (since 644 days) with SD (fig. 1). The response was independent of the receptor status (PDGFR- $\alpha,-\beta$, and KIT; table 6 ).

\section{Discussion}

This phase I/II dose escalation trial is the first to report on the combination of imatinib mesylate and vinorelbine in the treatment of advanced and/or MBC.

After the amended reduction of the imatinib dose from 600 to $400 \mathrm{mg}$ daily for tolerability reasons, dose escalation could be performed at the $100 \%$ level consisting of $400 \mathrm{mg}$ imatinib and $25 \mathrm{mg} / \mathrm{m}^{2}$ vinorelbine. Whilst the incidence of AEs causing study drug discontinuation showed no clear dose-dependent increase in the $400 \mathrm{mg}$ imatinib + vinorelbine regimens, dose adjustment or study drug interruption due to AEs was more frequently required with an increasing vinorelbine dose. No drug-related serious AEs (SAEs) were observed in the $400 \mathrm{mg}$ imatinib + vinorelbine regimens. None of the four deaths was drug related.

Although the RR with complete or partial remission in these patients with progressive or MBC was fairly low, a substantial number of patients across all dose levels showed clinical benefit. Patient numbers are too small to correlate drug dose with response or CBR. Expression of PDGFR- $\alpha$ and $-\beta$ were not differential as 20 of 22 cases were PDGFR- $\alpha$ positive and 21 of 22 PDGFR- $\beta$ negative. KIT-positive (7 of 22 ) cases had a less favorable prognosis than KIT- 


\section{Oncology}

\begin{tabular}{l|l}
\hline Oncology 2014;87:300-310 \\
\hline DOI: $10.1159 / 000365553$ & $\begin{array}{l}\text { ( 2)14 S. Karger AG, Basel } \\
\text { www.karger.com/ocl }\end{array}$ \\
\hline
\end{tabular}

Maass et al.: Final Safety and Efficacy Analysis of a Phase I/II Trial with Imatinib and Vinorelbine for Patients with Metastatic Breast Cancer

Fig. 1. Kaplan-Meier curves of the TTP by treatment and efficacy of the analyzable population. Due to the low number of cases, the Kaplan-Meier estimates for the time to response in the subgroups were not conclusive.

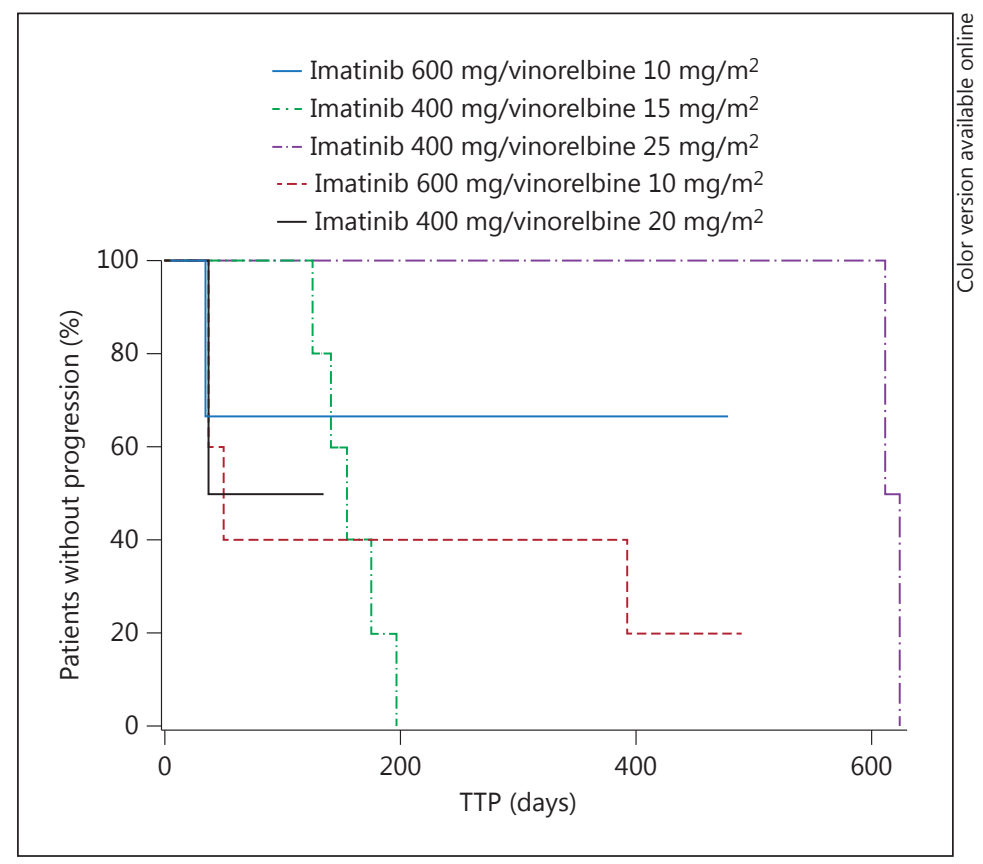

negative cases. A statistical correlation of growth receptor expression could not be performed as the numbers in the biological subgroups were too small.

As in previous trials (combining imatinib with capecitabine or docetaxel), the relevant toxicities were similar to the toxicities seen in this trial $[21,22]$. The combination of imatinib and vinorelbine commonly caused significant hematologic and gastrointestinal side effects (nausea) as well as fatigue with no clear correlation with the dosage. It is not possible to assign specific AEs to one of the drugs, although in the first cycle all patients were on singleagent imatinib for 1 week before vinorelbine was started. In this first week on trial, the most common side effects were moderate nausea and vomiting. All other effects must be attributed to the combination of the two drugs. Differences in quality of life in the different dose levels are statistically not meaningful. At baseline, 10 patients (55.6\%) presented with an ECOG status of 0 and 8 patients (44.4\%) with a status of 1 . At week 13, 1 patient (14.3\%) had an ECOG status of 0 and 6 patients (85.7\%) a status of 1 .

In studies investigating single-agent i.v. vinorelbine after previous chemotherapy in MBC, the RR was 35.7\%, the CBR 65.7\%, and the TTP approximately 126 days [29, 30]. Two phase II trials of single-agent imatinib mesylate in heavily pretreated MBC resulted in no clinical responses $[17,18]$. As single-agent activity among tyrosine kinase inhibitors has often been only modest in breast cancer, it was anticipated that the combination of imatinib mesylate and vinorelbine, based on preclinical studies suggesting synergy, would lead to encouraging results. Previous trials investigating combinations of imatinib and other chemotherapies did not show a better clinical activity compared to chemotherapy alone. A phase II trial investigated the combination of capecitabine and imatinib and resulted in an RR of $11 \%$ and a CBR of 52\%, without an enhanced efficacy compared to capecitabine alone [22]. Another phase II trial with imatinib and paclitaxel resulted in an RR of $13.2 \%$ and a CBR of $47.4 \%$; the TTP was 119 days [23]. A phase II trial of imatinib and docetaxel resulted in an RR of 22\% and a CBR of $67 \%$ [21]. Within the analyzable, partially heavily pretreated population of this study, the RR was $13.6 \%$, the CBR was $72.7 \%$, and the median TTP was 176 days. None of the other studies with combinations of imatinib with chemotherapy showed a better efficacy 


\section{Oncology}

\begin{tabular}{l|l}
\hline Oncology 2014;87:300-310 \\
\hline DOI: $10.1159 / 000365553$ & $\begin{array}{l}\text { @ 2014 S. Karger AG, Basel } \\
\text { www.karger.com/ocl }\end{array}$ \\
\hline
\end{tabular}

Maass et al.: Final Safety and Efficacy Analysis of a Phase I/II Trial with Imatinib and

Vinorelbine for Patients with Metastatic Breast Cancer

than the combination in this trial. In addition, RR and CBR were not superior, and the TTP in this combination study of imatinib and vinorelbine was remarkably longer (176 vs. 126 days).

Although the RR in these patients with progressive or MBC was low, the rate of patients who showed a clinical benefit was high. A number of patients across all dose levels showed clinical benefit for as long as 644 days. To allow a better patient selection and prediction of response, further correlative studies are ongoing.

\section{Conclusion}

After the reduction of the imatinib dose from 600 to $400 \mathrm{mg}$ daily for tolerability reasons, dose escalation could fully be performed. Nondose-related SAEs were observed in the $400 \mathrm{mg}$ imatinib + vinorelbine regimens. Although the rate of PR or CR in these patients with progressive or MBC was low, over $70 \%$ of the patients across all dose levels showed clinical benefit (response or SD) and an improved TTP. Correlative studies exploring biological subgroups further are ongoing and could help to better select patients for a therapy with imatinib and vinorelbine.

\section{Acknowledgement}

The trial was supported by Novartis Pharmaceutical, Germany.

\section{References}

1 Druker BJ; IRIS Study Group: STI571 (Gleevec/Glivec, imatinib) versus interferon (IFN) + cytarabine as initial therapy for patients with CML: results of a randomized study. Presentation at the 38th Annual Meeting of the American Society of Clinical Oncology, 2002.

2 Kantarjian H, Sawyers C, Hochhaus A, et al: Hematologic and cytogenetic responses to imatinib mesylate in chronic myelogenous leukemia. NEJM 2002;346:645-652.

-3 Frolov A, Chahwan S, Ochs M, Arnoletti JP, Pan ZZ, Favorova O, Fletcher J, von Mehren M, Eisenberg B, Godwin AK: Response markers and the molecular mechanisms of action of Gleevec in gastrointestinal stromal tumors. Mol Cancer Ther 2003;2:699-709.

4 Mundhenke C, Weigel MT, Sturner KH, Roesel F, Meinhold-Heerlein I, Bauerschlag DO, Schem C, Hilpert F, Jonat W, Maass N: Novel treatment of ovarian cancer cell lines with imatinib mesylate combined with paclitaxel and carboplatin leads to receptor-mediated antiproliferative effects. J Cancer Res Clin Oncol 2008;134: 1397-1405.

$\checkmark 5$ Apte SM, et al: Targeting the platelet-derived growth factor receptor in antivascular therapy for human ovarian carcinoma. Clin Cancer Res 2004;10:897-908.

6 Langley RR, et al: Activation of the platelet-derived growth factor-receptor enhances survival of murine bone endothelial cells. Cancer Res 2004;64:3727-3730.

7 Pietras K, et al: Inhibition of platelet-derived growth factor receptors reduces interstitial hypertension and increases transcapillary transport in tumors. Cancer Res 2001;61:2929-2934.

8 Pietras K, et al: Inhibition of PDGF receptor signaling in tumor stroma enhances antitumor effect of chemotherapy. Cancer Res 2002;62:5476-5484.

9 de Jong JS, et al: Expression of growth factors, growth inhibiting factors, and their receptors in invasive breast cancer. I: an inventory in search of autocrine and paracrine loops. J Pathol 1998;184:44-52.

$\checkmark 10$ Bhardwaj B, et al: Localization of platelet-derived growth factor beta receptor expression in the periepithelial stroma of human breast carcinoma. Clin Cancer Res 1996;2:773-782.

11 Marty M, Leandri S, Extra JM, et al: A phase II study of vinorelbine (NVB) in patients (pts) with advanced breast cancer (BC). Proc Am Assoc Cancer Res 1989;30:256.

12 Roche H, Fumoleau P, Tresca P, et al: Vinorelbine, a new active drug in breast carcinoma: results of an ARTAC phase II trial. Ann Oncol 1990;1:36.

13 Green S, Weiss GR: Southwest Oncology Group standard response criteria, endpoint definitions and toxicity criteria. Invest New Drugs 1992;10:239-253. 


\section{Oncology}

\begin{tabular}{l|l}
\hline Oncology 2014;87:300-310 \\
\hline DOI: 10.1159/000365553 & $\begin{array}{l}\text { C 2014 S. Karger AG, Basel } \\
\text { www.karger.com/ocl }\end{array}$ \\
\hline
\end{tabular}

Maass et al.: Final Safety and Efficacy Analysis of a Phase I/II Trial with Imatinib and Vinorelbine for Patients with Metastatic Breast Cancer

14 Paulsson J, Sjöblom T, Micke P, et al: Prognostic significance of stromal platelet-derived growth factor$\beta$-receptor expression in human breast cancer. Am J Pathol 2009;175:334-341.

15 Weigel MT, Meinhold-Heerlein I, Bauerschlag DO, Schem C, Bauer M, Jonat W, Maass N, Mundhenke C: Combination of imatinib and vinorelbine enhances cell growth inhibition in breast cancer cells via PDGFR beta signalling. Cancer Lett 2009;273:70-79.

16 Vlahovic G, Rabbani ZN, Herndon JE 2nd, Dewhirst MW, Vujaskovic Z: Treatment with imatinib in NSCLC is associated with decrease of phosphorylated PDGFR-beta and VEGF expression, decrease in interstitial fluid pressure and improvement of oxygenation. Br J Cancer 2006;95:1013-1019.

-17 Modi S, Seidman AD, Dickler M, Moasser M, D’Andrea G, Moynahan ME, Menell J, Panageas KS, Tan LK, Norton L, Hudis CA: A phase II trial of imatinib mesylate monotherapy in patients with metastatic breast cancer. Breast Cancer Res Treat 2005;90:157-163.

-18 Cristofanilli M, Morandi P, Krishnamurthy S, Reuben JM, Lee BN, Francis D, Booser DJ, Green MC, Arun BK, Pusztai L, Lopez A, Islam R, Valero V: Hortobagyi GN: Imatinib mesylate (Gleevec) in advanced breast cancerexpressing C-Kit or PDGFR-beta: clinical activity and biological correlations. Ann Oncol 2008;19:1713-1719.

19 Weigel MT, Dahmke L, Schem C, Bauerschlag DO, Weber K, Niehoff P, Bauer M, Strauss A, Jonat W, Maass N, Mundhenke C: In vitro effects of imatinib mesylate on radiosensitivity and chemosensitivity of breast cancer cells. BMC Cancer 2010;10:410.

20 Liu J, Liao S, Huang Y, et al: PDGF-D improves drug delivery and efficacy via vascular normalization, but promotes lymphatic metastasis by activating CXCR4 in breast cancer. Clin Cancer Res 2011;17:3638-3648.

21 Pishvaian M, Slack R, Koh EY: A phase I clinical trial of the combination of imatinib and paclitaxel in patients with advanced or metastatic solid tumors refractory to standard therapy. Cancer Chemother Pharmacol 2012; 70:843-853.

22 Yardley DA, Burris HA, Markus T, et al: Phase II trial of docetaxal plus imatinib mesylate in the treatment of patients with metastatic breast cancer. Clin Breast Cancer 2009;9:237-242.

23 Khayat D, Covelli A, Variol P, et al: Phase I and pharmacologic study of intravenous vinorelbine in patients with solid tumors (abstract 1518). Proc Am Soc Clin Oncol 1995;14:469.

24 Fumoleau P, Delgado FM, Delozier T, et al: Phase II trial of weekly intravenous vinorelbine in first line advanced breast cancer chemotherapy. J Clin Oncol 1993;11:1245-1252.

25 Canobbio L, Boccardo F, Pastorino G, et al: Phase-II study of Navelbine in advanced breast cancer. Semin Oncol 1989;16(suppl 4):33-36.

26 Garcia-Conde J, Lluch A, Martin M, et al: Phase II trial of weekly IV vinorelbine in first-line advanced breast cancer chemotherapy. Ann Oncol 1994;5:854-857.

27 Bruno S, Puerto VL, Mickiewicz E, et al: Phase II study of weekly vinorelbine as a single agent in first-line advanced breast cancer chemotherapy. Am J Clin Oncol 1995;18:392-396.

28 Terenziani M, Demicheli R, Brambilla C, et al: Vinorelbine: an active, non cross-resistant drug in advanced breast cancer. Results from a phase II study. Breast Cancer Res Treat 1996;39:285-291.

29 Chew HK, Barlow WE, Albain K, et al: A phase II study of imatinib mesylate and capecitabine in metastatic breast cancer: Southwest Oncology Group Study 0338. Clin Breast Cancer 2008;8:511-515.

30 Gasparini G, Caffo O, Barni S, Frontini L, Testolin A, Guglielmi RB, Ambrosini G: Vinorelbine is an active antiproliferative agent in pretreated advanced breast cancer patients: a phase II study. J Clin Oncol 1994;12: 2094-2101. 